\title{
Germination, Forage Yield, and Seed Produc- tion of American Sloughgrass (Beckmannia syzigachne)
}

\author{
A. BOE AND R. WYNIA
}

\section{Abstract}

Germination, forage yield, and seed production characteristics were studied in American sloughgrass (Beckmannia syzigachne (Steud.) Fern.), a valuable wetland forage species in the northwestern and northcentral states. Germination of field-collected caryopses from northeastern Montana, stored at $7^{\circ} \mathrm{C}$ for 60 days postharvest, was significantly $(P<0.05)$ higher under alternating temperatures $\left(7^{\circ} \mathrm{C}\right.$ for $15 \mathrm{~h}$ and $21^{\circ} \mathrm{C}$ for $9 \mathrm{~h}$ in each $24-\mathrm{h}$ period) than at constant $21^{\circ} \mathrm{C}$. Germination percentages greater than $60 \%$ were found for freshly harvested greenhouse-produced spikelets and caryopses after 14 days in complete darkness, and no significant differences were detected between complete darkness and $15 \mathrm{~h}$ dark $/ 9 \mathrm{~h}$ light treatments under alternating temperatures. Greenhouse-produced caryopses were significantly heavier and exhibited significantly higher germination than caryopses from field collections. A Montana field collection and a seed increase of that collection significantly $(P<0.05)$ outyielded a local South Dakota collection for both forage and seed at Brookings, South Dakota. Overall mean dry matter forage and mature seed yields were 2,700 and $540 \mathrm{~kg} / \mathrm{ha}$, respectively. Forage yields at early-head of the seed increase population planted at 15,18 , and $21 \mathrm{~kg} / \mathrm{ha}$ were not significantly different and had an overall mean of $5,000 \mathrm{~kg} / \mathrm{ha}$. These preliminary data indicate that the potential of $B$. syzigachne as a cultivated forage for cropland depressions in the Northern Great Plains does not appear to be limited by complex germination requirements, low forage yield, or weak seed production.

American sloughgrass (Beckmannia syzigachne (Steud.) Fern.) is the North American native of a bispecies genus that is widespread in the cooler parts of Eurasia and North America. $B$. syzigachne is present in marshes and along ditches throughout the northwest and northcentral states and is occasional in the Northeast (Gould and Shaw 1983). It frequently colonizes denuded wetland soils resulting from mud flat exposure, livestock grazing, or tillage (Walker and Coupland 1968, Stewart and Kantrud 1971, Millar 1973, 1976). As early as 1896 , Beal pointed out that $B$. syzigachne was a forage of some prominence west of the Mississippi River. It is palatable to livestock (Hitchcock 1951, Stevens 1963 ) and is frequently hayed or grazed (Clarke and Tisdale 1945). Forage nutritional data (Clarke and Tisdale 1945, National Academy of Science 1971) indicate it is high in protein and nonstructural carbohydrates. Studies in the USSR (Komarov 1963) indicated that Beckmannia eruciformis (L.) Host. was similar to timothy in forage quality, gave satisfactory hay yields, good aftergrowth, and was tolerant of salinity. Several authors (Hitchcock 1951, Moss 1959, and Koyama and Kawano 1964) have pointed out strong morphological similarities between B. syzigachne and B. eruciformis, and Hulten (1968) considered them to be synonymous.

Hoffman et al. (1980) reported low germination percentages for B. syzigachne, obtaining a high of $26 \%$ from disseminules that had overwintered dry and were tested under ambient April light and

Authors are assistant professor and graduate assistant, Department of Plant Science, South Dakota State University, Brookings 57007.

This article is a contribution from South Dakota Agricultural Experiment Station Journal Series No. 1909.

Manuscript accepted June 12, 1984. temperatures at Vermillion, South Dakota. They also indicated that darkness inhibited germination.

In a preliminary study, Boe and Evans (1981) reported intact spikelets and caryopses freed from spikelet bracts exhibited poor germination at room temperature and disappointing emergence in greenhouse plantings. However, they did observe up to $91 \%$ germination in 15 days under an alternating temperature regime of $7^{\circ} \mathrm{C}$ for 15 hours and $21^{\circ} \mathrm{C}$ for 9 hours.

Our objectives were: (1) to investigate germination characteristics of $B$. syzigachne, and (2) to investigate forage yield and seed production potentials of $B$. syzigachne in field plantings near Brookings, S. Dak.

\section{Materials and Methods}

\section{Germination Studies}

Spikelets were collected along a creek in northeastern Montana, near Outlook, in August 1979, 1980, and 1981 and along a pond near Brookings, S. Dak., in August 1982. Germination studies were conducted on spikelets and caryopses from Montana collections and on spikelets and caryopses produced in the greenhouse from the 1979 and 1980 collections. A South Dakota Seed Blower was used to separate inert matter from spikelets containing caryopses. A rubber threshing board was employed to free caryopses from spikelet bracts. Spikelets and caryopses were considered germinated when coleoptiles were visible. Analyses of variance were conducted on germination percentages transformed by the arcsine transformation (Sokal and Rohlf 1969).

Experiment 1: This experiment was initiated 28 April 1981. Spikelets and caryopses produced in the greenhouse in March 1981 and not previously exposed to a cold period were placed on blotters moistened with deionized water in germination trays. A factorial arrangement of treatments within a completely randomized design was employed. Half the germination trays were kept in darkness at $7^{\circ} \mathrm{C}$ for 15 hours and were subsequently transferred to a laboratory bench facing a large north window from 0800 to 1700 hours each day. Temperatures in the laboratory were noted at 0800,1200 , and 1700 hours and averaged $21 \pm 1^{\circ} \mathrm{C}$. Ambient light entered through the window and no auxiliary lighting was employed. The remaining trays were double-wrapped with aluminum foil to occlude light, but subjected to the same temperature fluctuation. Two replications of 50 caryopses and 50 spikelets were used for each treatment. Germination was noted at 14 days.

Experiment 2: This experiment was initiated 30 November 1981. Caryopses from the 1981 field harvest, stored at $7^{\circ} \mathrm{C}$ since immediately after harvest, were placed in germination trays in a completely randomized design with a factorial arrangement of 4 light and temperature treatment combinations. Temperature effects employed were: (1) the alternating regime of Experiment 1, and (2) constant $21^{\circ} \mathrm{C}$. Light effects employed were the same regime as Experiment 1 . Unwrapped trays that were kept in the laboratory were covered with black plastic from 1700 to 0800 hours, while the unwrapped trays subjected to the alternating temperatures regime were kept in darkness at $7^{\circ} \mathrm{C}$ for the same period each day. Three replications of 100 caryopses/treatment combination were used. Germination was noted at 14 and 21 days. 
Experiment 3: This experiment was initiated 10 March 1982. Caryopses from 1979, 1980, and 1981 field collections, and 1980 and 1981 greenhouse increases of 1979 and 1980 field collections, all stored at $7^{\circ} \mathrm{C}$ since immedia tely after harvest, were subjected to the temperature and light regime described in Experiment 1 (15 h dark $/ 7^{\circ} \mathrm{C}$ and $9 \mathrm{~h}$ light $/ 21^{\circ} \mathrm{C}$ ). Three replications of 100 caryopses/lot were used. Germination was noted at 14 and 21 days. Weights were determined for 2 random 50-caryopses samples from each lot.

\section{Forage Yield, Seed Production, and Field Germination Studies}

In November 1981 the initial forage yield trial (Trial 1) was planted on a Lamoure silty clay loam, nearly level [fine-silty, mixed (Calcareous), frigid Cumulic Haplaquolls] soil approximately 2.0 $\mathrm{km}$ north of Brookings. Three different seeding rates $(13,18$, and $23 \mathrm{~kg} / \mathrm{ha}$ ) of the $198 \mathrm{l}$ field-collected lot were planted in a randomized complete block design. Planting was done with a 4 -row $(30-\mathrm{cm}$ row-spacing) belt seeder equipped with double-disc openers and depth bands. Individual plot size was 1.2 by $6.3 \mathrm{~m}$. On 9 July 1982 , 2 replicates in Trial I were harvested for forage yield. Plants were in late-boot to early-flower stages. On 2 August 1982, the third replicate of Trial 1 was harvested for seed yield.

In November 1982, 2 additional 3-replicate yield trials were planted near Brookings. Trial 2 was planted adjacent to Trail 1 , and was comprised of 3 seed lots as follows: (1) 1981 Montana field collection (MT81); (2) 1982 field collection from a pond near Brookings (BP82); and (3) 1982 seed increase at Brookings from the 1981 Montana field collection (SD82). Seeding rate was 18 $\mathrm{kg} / \mathrm{ha}$. Trial 3 was planted on a Vienna loam, nearly level [fineloamy, mixed Udic Haploborolls] on the Agronomy Farm near the SDSU campus, and incorporated 3 different seeding rates $(15,18$, and $21 \mathrm{~kg} / \mathrm{ha}$ ) of the 1982 seed increase material (SD82). Planting method and plot size for Trials 2 and 3 were as described for Trial 1 . Trials 2 and 3 were hand-wecded once during June 1983. On 11 July 1983, Trial 3 was harvested for forage yield. Plants were in late-boot to early head stages. Trial 2 was harvested on 3 August 1983 for forage and mature seed yields. Forage moisture samples were taken from each plot at harvest time for later calculation of dry matter yields. Panicles were disarticulated by hand and fertile spikelets were separated from inert material with a South Dakota Seed Blower. Seed yields were determined based on total weight of fertile spikelets from each plot.

In October 1983, six 60-cm² plots were randomly selected within the 2 middle border rows of Trial 3. The border rows had not been harvested for seed, and mature spikelets produced in those rows had disarticulated from the rachis in August. Within each of these plots, which were excavated to a depth of $2.0 \mathrm{~cm}$, numbers of fall-germinated seedlings and nongerminated spikelets were determined after the soil had been carefully removed in the laboratory by rinsing on a fine-mesh screen.

\section{Results and Discussion}

\section{Germination Studies}

Experiment 1: Greenhouse-produced spikelets and caryopses previously stored at room temperature for $\mathbf{4 5}$ days post-harvest, when subjected to alternating temperatures and complete darkness, exhibited mean germination percentages comparable to those in uncovered trays (Table 1), indicating darkness did not severcly inhibit germination.

Experiment 2: Caryopses subjected to the alternating temperature regime achieved significantly higher $(P<0.05)$ germination percentages than those maintained at $21^{\circ} \mathrm{C}$ (Table 1). Within each of the 2 temperature treatments, no difference was detected between trays kept in the dark and those exposed to ambient April light from 0800 to 1700 hours each day. Alternating temperatures have been shown to enhance germination of numerous range grasses (Toole 1940). However, McElgunn (1974) reported that 10
Table 1. Effects of temperature, spikelet bract removal, and seed source on laboratory germination of American sloughgrass.*

\begin{tabular}{|c|c|c|}
\hline \multirow[b]{2}{*}{ Treatment } & \multicolumn{2}{|c|}{ Days } \\
\hline & 14 & 21 \\
\hline $\begin{array}{l}\text { Experiment } \text { I }^{1} \\
\text { Caryopses; } 15 \mathrm{~h} \text { dark } / 9 \mathrm{~h} \text { light } \\
\text { Caryopses; dark } \\
\text { Intact spikelets; } 15 \mathrm{~h} \text { dark } / 9 \mathrm{~h} \text { light } \\
\text { Intact spikelets; dark }\end{array}$ & $\begin{array}{l}61 \mathrm{a} \\
48 \mathrm{a} \\
42 \mathrm{a} \\
65 \mathrm{a}\end{array}$ & \\
\hline $\begin{array}{l}\text { Experiment } 2 \\
\text { Alternating temperature'; dark } \\
\text { Alternating temperature; } 15 \mathrm{~h} \text { dark } / 9 \mathrm{~h} \\
\text { light } \\
\text { Constant } 21^{\circ} \mathrm{C} \text {; dark } \\
\text { Constant } 21^{\circ} \mathrm{C} ; 15 \mathrm{~h} \text { dark } / 9 \mathrm{~h} \text { light }\end{array}$ & $\begin{array}{r}47 \mathrm{a} \\
35 \mathrm{a} \\
1 \mathrm{~b} \\
2 \mathrm{~b}\end{array}$ & $\begin{array}{r}- \\
43 \mathrm{a} \\
1 \mathrm{~b} \\
3 \mathrm{~b}\end{array}$ \\
\hline $\begin{array}{l}\text { Experiment } 32 \\
1980 \text { greenhouse } \\
1981 \text { greenhouse } \\
1979 \text { field } \\
1980 \text { field } \\
1981 \text { field }\end{array}$ & $\begin{array}{l}96 \mathrm{a} \\
91 \mathrm{a} \\
57 \cdot \mathrm{b} \\
60 \mathrm{~b} \\
70 \mathrm{~b}\end{array}$ & $\begin{array}{l}96 \mathrm{a} \\
92 \mathrm{a} \\
60 \mathrm{~b} \\
62 \mathrm{~b} \\
71 \mathrm{~b}\end{array}$ \\
\hline
\end{tabular}

* Mean in same column followed by a different letter are significantly different at the the $5 \%$ level. - indicates missing data.

the $5 \%$ level. - indicates missing data. Temperatures employed were $7^{\circ} \mathrm{C}$ for $15 \mathrm{~h}$ and $21^{\circ} \mathrm{C}$ for $9 \mathrm{~h}$ in each $24 \mathrm{~h}$ period.
'Temperature and light treatments employed were $7^{\circ} \mathrm{C}$ in dark for $15 \mathrm{~h}$ and $21^{\circ} \mathrm{C}$ in light for $9 \mathrm{~h}$ in each $24 \mathrm{~h}$ period.

grass species averaged higher germination at constant $21^{\circ} \mathrm{C}$ than at $7^{\circ} \mathrm{C}$ for 12 hours and $18^{\circ} \mathrm{C}$ for 12 hours.

Experiment 3: The highest germination percentages were found for the greenhouse-produced lots (Table 1). After 14 days, the 1980 and 1981 greenhouse-produced lots exhibited mean germination percentages of 96 and $91 \%$, respectively. Greenhouse-produced caryopses were significantly $(P<0.05)$ heavier than caryopses from field collections. Mean 50-caryopses weights were 16.8 and $13.2 \mathrm{mg}$ for greenhouse-produced and field-collected lots, respectively. Higher germination percentages and faster germination rates for large compared to small seed have been reported for numerous range (Green and Hansen 1969) and pasture (Kneebone 1972) grasses.

\section{Forage Yield, Seed Production, and Field Germination Studies}

No significant differences in forage yield in 1982 were detected among the 3 planting rates in the 1981 trial. The overall dry matter forage yield mean was $2,800 \mathrm{~kg} / \mathrm{ha}$. The overall seed yield mean was $650 \mathrm{~kg} / \mathrm{ha}$.

Forage and seed yield data obtained in 1983 from the 21982 yield trials are presented in Table 2 . In Trial 2, significant differen-

Table 2. Mean dry matter forage and seed yields in 1983 for two American sloughgrass yield trials planted at Brookings, SD in November 1982.*

\begin{tabular}{|c|c|c|c|c|}
\hline \multicolumn{3}{|c|}{ Trial 2} & \multicolumn{2}{|c|}{ Trial 3} \\
\hline Seed source & Forage yield & Seed yield & Seeding rate & Forage yield \\
\hline & \multicolumn{4}{|c|}{ - $\mathrm{kg} / \mathrm{ha}$} \\
\hline SD 82 & $3250 \mathrm{a}$ & $620 a$ & 15 & $4330 \mathrm{a}$ \\
\hline MT 81 & 2850 a & $560 \mathrm{a}$ & 18 & 5380 a \\
\hline BP 82 & $1990 \mathrm{~b}$ & $440 \mathrm{~b}$ & 21 & $5300 \mathrm{a}$ \\
\hline
\end{tabular}

* Means in the same column followed by different letter are significantly different at the $5 \%$ level.

ces were found among seed sources for both forage and seed yields. Seed sources of Montana origin significantly $(P<0.05)$ outyielded the local field collection for both forage and seed. Mean forage 
yields ranged from 3,250 to $1,990 \mathrm{~kg}$ / ha for the 1982 seed increase of material collected in Montana in 1981 and the local collection, respectively. In Trial 3, no significant differences were detected among the 3 planting rates. Although initial emergence appeared to be positively associated with planting rate in Trial 3, failure to detect differences in forage yield among planting rates may be due to this species' high tillering capacity. Overall dry matter yield means were 3,240 (forage plus seed) and $5,000 \mathrm{~kg} /$ ha for Trials 2 and 3 , respectively. Differences in harvest time may partially explain these yield differences, since Trial 3 was harvested at early-head while Trial 2 was harvested at seed maturity when general vegetative deterioration was quite evident. Also, the highest yielder in Trial 2 (SD 82) was the seed source for the planting rate study (Trial 3 ).

Numbers of seedlings and nongerminated spikelets obtained in October 1983 from 6 sample plots within the border rows of the 1982 Trial 3 averaged $54,399.8 \pm 6,248.0$, and $65,985.4 \pm 17,668.8 / \mathrm{m}^{2}$, respectively. Percent germination of spikelets (calculated as total number of seedlings/ (total number of seedlings + total number of nongerminated spikelets obtained from the 6 plots)) was $45 \%$. This percentage was determined from spikelet numbers and was not adjusted to represent only those spikelets that contained caryopses. Since $100 \%$ caryopses set in field-grown spikelets seems unlikely, field germination percentage calculated for caryopses may be expected to be somewhat higher. However, Boe and Evans (1981) reported $100 \%$ self-fertility and caryopses set in inflorescences of greenhouse-grown plants.

\section{Conclusions}

The potential forage values of many native species are unrealized. However, several factors that may limit the number of natives that can be profitably incorporated into cultivated forage systems are: (1) complex germination requirements that inhibit rapid and uniform germination, (2) low forage yield potential, and (3) poor seed production. This preliminary research was aimed at determining if any of these factors were characteristic of $B$. syzigachne, a native species recognized as a valuable component of wetland forage.

We observed $45 \%$ germination in the field in October for spikelets that had matured and disarticulated in the summer, and up to $96 \%$ germination for freshly harvested caryopses under alternating temperatures in the laboratory. These data indicated a lack of complex seed dormancy characteristics in the germplasm studied. Nonrestrictive germination requirements and prolific seed production capabilities may bc important characteristics associated with this species' ability to rapidly colonize exposed mudflats and disturbed wetlands. Dix and Smeins (1967) reported that $B$. syzigachne was commonly found in cropland depressions in eastern North Dakota. The seed unit that disarticulates from the rachis at maturity is a firm, glabrous, free-flowing spikelet that presents no difficulties for conventional planting equipment.

Forage and seed yields under dryland conditions at 2 locations were similar to long-term averages for smooth bromegrass (Bromus inermis Leyss) in the same area (Ross and Krueger 1976). This indicated that high yielding stands of $B$. syzigachne could be successfully established from dormant plantings made after freezeup.
In the Northern Great Plains, there is a need for more efficient utilization of seasonal wetlands where cropping with cereal or row crops is unpredictable due to high spring-time moisture levels, and where dense sod-forming perennial grasses, such as reed canarygrass (Phalaris arundinacea L.) and creeping foxtail (Alopecurus arundinaceus Poir.), are not desired. These data indicate that $B$. syzigachne's potential for utilization as a pasture or hay crop does not appear to be limited by complex germination requirements, low forage yield potential, or poor seed production. At this point, more extensive ecotype collection and evaluation for forage yield and quality and adaptability to short-term forage production in seasonal wetlands seems warranted.

\section{References}

Beal, W.J. 1896. Grasses of North America. Holt Publishing Co.

Boe, A., and J. Evans. 1981. Spikelet characteristics and germination of American sloughgrass (Beckmannia syzigachne (Steud.) Fern.) from northeastern Montana. S.D. Acad. Sci. 60:170.

Clarke, S.E., and W.E. Tisdale. 1945. The chemical composition of native forage plants of southern Alberta and Saskatchewan in relation to grazing practices. Can. Dep. Agr. Pub. 769.

Dix, R.L., and F.E. Smeins. 1967. The prairie, meadow, and marsh vegetation of Nelson County, North Dakota. Can. J. Bot. 45:21-58.

Gould, F.W., and R.B. Shaw. 1983. Grass systematics. 2nd Ed. Texas A\&M University Press.

Green, N.E., and R.M. Hansen. 1969. Relationship of seed weight to germination of six grasses. J. Range Management. 22:133-134.

Hitchcock, A.S. 1951. Manual of the grasses of the United States. 2nd ed., revised by A. Chase. USDA Misc. Publ. 200.

Hoffman, G.R., M.B. Hogan, and L.D. Stanley, 1980. Germination of plant species common to reservoir shores in the Northern Great Plains. Bull. Torr. Bot. Club. 107:506-513.

Hulten, E. 1968. Flora of Alaska and Neighboring Territories. Stanford Univ. Press, Calif.

Kneebone, W.R. 1972. Breeding for seedling vigor. p. 91-98. In: V.B. Youngner and C.M. McKell (eds.) The biology and utilization of grasses. Academic Press, New York.

Komarov, V.L. (Ed.). 1963. Flora of the USSR - Volume II. Published for the National Science Foundation, Washington, D.C. and the Smithsonian Institute by the Israel Program for Scientific Translations.

Koyama, T., and S. Kawano. 1964. Taxa of Grasses. Can. J. Bot. 42:875-879.

McElgunn, J.D. 1974. Germination response of forage grasses to constant and alternating temperatures. Can. J. Plant Sci. 54:265-270.

Millar, J.B. 1973. Vegetation changes in shallow marsh wetlands under improving moisture regime. Can. J. Bot. 51:1443-1457.

Millar, J.B. 1976. Wetland classification in western Canada. Can. Wildl. Serv. Rep. Ser. No. 37.

Moss, E.H. 1959. Flora of Alberta. Univ. Toronto Press, Canada.

National Academy of Science. 1971. Atlas of nutritional data on United States and Canadian feeds. Nat. Acad. Sci., Washington, D.C.

Ross, J.G., and C.R. Krueger. 1976. Grass species and variety performance in South Dakota. S.D. Agr. Exp. Sta. Bull. 642.

Sokal, R.R., and F.J. Rohlf. 1969. Biometry. W.H. Freeman and Company, San Francisco, Calif.

Stevens, O.A. 1963. Handbook of North Dakota plants. North Dakota Inst. Environ. Studies, Fargo.

Stewart, R.E., and H.A. Kantrud. 1971. Classification of natural ponds and lakes in the glaciated prairie region. U.S. Fish and Wildl. Serv. Resour. Pub. 92.

Toole, V.K. 1940. Germination requirements of the seed of some introduced and native range grasses. Proc. Ass. Off. Seed. Anal. 30:227-243.

Walker, B.H., and R.T. Coupland. 1968. An analysis of vegetationenvironment relationships in Saskatchewan sloughs. Can. J. Bot. 46:509-522. 